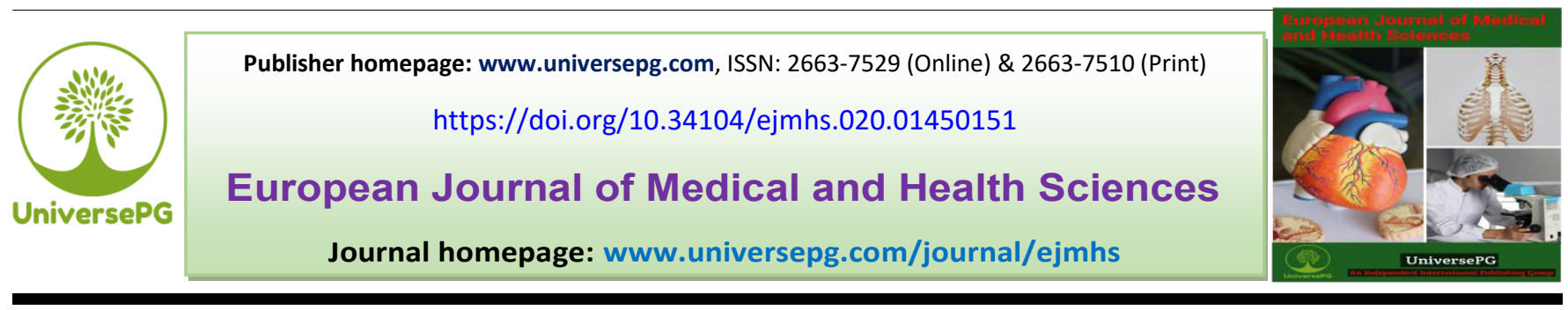

\title{
Phytochemical Screening and Bioactivity Determination of Ethyl Acetate and Methanolic Extracts of Leaf and Bark of the Plant Nyctanthes arbortristis $\mathbf{L}$.
}

\author{
Saduddin Talukder ${ }^{1}$, Mohammad Sarowar Uddin ${ }^{1}$, Mahmuda Ferdous ${ }^{1}$, and Prodip Kumar Baral ${ }^{1}$ * \\ ${ }^{1}$ Department of Pharmacy, Noakhali Science and Technology University, Noakhali-3814, Bangladesh. \\ *Correspondence: pkb.phar@nstu.edu.bd
}

\begin{abstract}
The present study targeted to evaluate the phytoconstituents of Nyctanthes arbortristis Linn., and its biological activity. By solvent extraction procedure, a total of four extracts were designated from the leaf and bark of the plant using two solvents (leaf extract in ethyl acetate and methanol: NALE \& NALM; bark extract in ethyl acetate and methanol: NABE \& NABM). Phytochemical screening was conducted by qualitative analysis and thin-layer chromatography. Parallelly, antioxidant property (by DPPH free radical scavenging method) and antimicrobial activity (by disk diffusion method) were also investigated to determine bioactivity. The presence of alkaloids and glycosides was detected by qualitative phytochemical assay of the extracts. Furthermore, TLC successfully observed the versatility of the compound's presence, such as phenolic compounds, different alkaloids, and glycosides. In DPPH assay, methanolic extracts are highly capable of scavenging the radicals than the ethyl acetate extracts. Surprisingly, IC50 for NABM $(1.69 \mu \mathrm{g} / \mathrm{ml})$ is less than ascorbic acid $(3.58 \mu \mathrm{g} / \mathrm{ml})$, which is an exploration of excellent antioxidant potential of the plant. But any extracts showed no positive result in the antimicrobial test against gram-positive or gram-negative bacteria, even against yeast.
\end{abstract}

Keywords: Phytoconstituents, Thin layer chromatography, Alkaloids, Glycosides, and Free radical scavenging.

\section{INTRODUCTION:}

Phytochemicals, labeled as primary or secondary metabolites, primarily focus on their function in the plants' metabolism. Studies have discovered a broad array of functional capability on human physiology of secondary phytochemicals such as alkaloids, terpenes, flavonoids, curcumins, saponins, phenolics, flavonoids, and glucosides (Makkar et al., 2007). A wide range of secondary metabolites is found in the plant family Oleaceae having high level of pharmacological values (Huang et al., 2019). But, little is known regarding the chemistry and pharmacology of $N$. arbortristis Linn., (Night jasmine) of this family.

UniversePG I www.universepg.com
It is a shrub of $10 \mathrm{~m}$ long with flowers of high fragnance which bloom at night and fall off before sunrise. N. arbor-tristis is indigenous to India, widely distributed in South East Asia, and also cultivated in tropical and subtropical regions globally (Rani et al., 2012). Earlier studies on this plant revealed that several iridoid glycosides (Sing et al., 1995; Tuntiwachwuttikul et al., 2003, Khanapur et al., 2014), three carotenoid glucosides (Mathuram and Kundu, 1991), phenyl-propanoid glycoside (Tuntiwachwuttikul et al., 2003), desrhamnosylverbascoside (Mathuram et al., 1997), rengyolone (Tuntiwachwuttikul et al., 2003), 6ß hydroxylloganin, nyctanthoside (Jensen 
and Nielsen, 1982) were isola-ted from the plant. $N$. arbortristisis a mythological plant and has high therapeutic values used in Homeopathic, Sidha, Unani, and Ayurveda (Rani et al., 2012). The commonly used case highlights its anti-helminthic and antipyretic effects (Khanapur et al., 2014). Furthermore, the isolated pure compounds possess significant bioactivity like anti-inflammatory, antiallergic, immunemodulatory, anticancer, antiviral, and antileishmania (Agrawal and Pal, 2013; Shukla et al., 2011). Therefore, the present investigation has an aim to determine the diversity and bioactivity of several plant parts using the solvents of different polarity.

\section{MATERIALS AND METHODS:}

Collection and drying of the plant - The leaves and bark of $N$. arbortristis were collected from several household gardens in Noakhali, Bangladesh, and identified by botanists. The leaves and bark are dried in room temperature and humidity. It is then heated at $60^{\circ} \mathrm{C}$ in an oven for 10 hours for the final drying before the grinding.

Extraction of phytochemicals - Each powdered portion was soaked into ethyl acetate and methanol for $1^{\text {st }} 7$ days and $2^{\text {nd }} 7$ days. After every seven days, the filtrates were subjected to cold extraction procedures using a rotary evaporator. The final concentrated four extracts preserved in fridge labeling NALE, $N$. arbortistis leaf in ethyl acetate; NALM, $N$. arbortistis leaf in methanol; NABE, N. arbortistis bark in ethyl acetate; NABM, N. arbortistis bark in methanol.

\section{Phytochemical screening}

Detection of alkaloids - The extracts were dissolved individually in dilute Hydrochloric acid. Then alkaloid detection was carried out treating the sample with Mayer's reagent (Potassium Mercuric Iodide), Wagner's reagent (Iodine in Potassium Iodide), and Dragendorff's reagent (solution of Potassium Bismuth Iodide). The formation of turbidity or precipitation scored positive for alkaloids (Kaur and Arora, 2009).

Tests for glycosides - Keller-Killiani test: Dissolved plant extracts $(100 \mathrm{mg})$ in absolute methanol $(2 \mathrm{ml})$ were treated with glacial acetic acid $(2 \mathrm{ml})$. Then, $5 \%$ of ferric chloride solution $(1 \mathrm{ml})$ and concentrated sulfuric acid (1ml) were added. The appearance of a reddish-brown ring indicated the presence of cardiac glycoside (Harborne, 2005).

UniversePG I www.universepg.com
Borntrager test - Filtrate of 100mg plant extracts in chloroform $(5 \mathrm{ml})$ was shaken with an equal volume of $10 \% \mathrm{NH}_{4} \mathrm{OH}$. The appearance of pink-violet or red color in the bottom layer is positive for anthraquinones (Raaman, 2006).

\section{Test for steroids}

Salkowski's Test - Filtrates of extracts with chloroform were treated concentrated sulfuric acid. The appearance of reddish-brown color at the interface after shaking indicates steroids' presence (Joshi et al., 2013).

Liebermann Burchard's test - Extracts in chloroform were treated with acidic anhydride, boiled, cooled and followed by concentrated sulfuric acid addition. Formation of greenish transient color scores positive for steroids (Raaman, 2006).

Test for Saponins - $20 \mathrm{ml}$ diluted extracts were shaken in a graduated cylinder for 15 minutes. A onecentimeter layer of foam indicated the presence of saponins (Raaman, 2006).

\section{Thin Layer Chromatography (TLC)}

Detection of major phytochemicals was also carried out by pre-coated (Kiesel gel 60 PF254) TLC plate (Wagner et al., 2004). Mix solvents (Toluene: Ethyl acetate $=90 \%: 10 \%)$ is used to plate development and observed under visible light as well as UV light (254 $\mathrm{nm}$ and $365 \mathrm{~nm}$ ). The number and diversity of colors with different $\mathrm{Rf}$ differentiate the types of compounds present in the extracts.

Free Radical Scavenging Activity (DPPH Method) The hydrogen-donating abilities of extracts were examined through the method described by Khanapur et al., 2014, with a little bit modification. Briefly, 1.6 $\mathrm{mg}$ of different extracts was dissolved in methanol to get a mother solution. Serial dilution of each $2 \mathrm{ml}$ mother and addition with $2 \mathrm{ml} \mathrm{2,} \mathrm{2-diphenyl-1-}$ picrylhydrazyl in methanol $(20 \mu \mathrm{g} / \mathrm{ml})$ got a total of 4 $\mathrm{ml}$ mixture of different sample concentration from 200.0 to $0.78125 \mu \mathrm{g} / \mathrm{ml}$. Methanol (95\%) and ascorbic acid (same concentrations as a sample) were used as blank and reference. The UV absorbance was taken at $517 \mathrm{~nm}$ after 30 minutes' incubation at a dark place. $50 \%$ of DPPH free radical scavenging concentration. $\left(\mathrm{IC}_{50}\right)$ has been measured using the regression equation attain from the values of at least five consequent dilutions. 
Antimicrobial Test - The antibacterial potential of the four extracts of $N$. arbortristis was determined by the disc diffusion method described by Santoyo et al., 2005 against two gram-positive bacteria (Staphylococcus aureus, Enterococcus sp.), three gram-negative bacteria (Escherichia coli, Salmonella typhi, Pseudomonas sp.), and one fungus ( $S$. cerevisiae). Each disc of plant extracts contained $40 \mu \mathrm{g}$ and the zone of inhibition compared to ciprofloxacin $(20 \mu \mathrm{g} / \mathrm{disc})$ and ketoconazole $(20 \mu \mathrm{g} / \mathrm{disc})$.

\section{Qualitative Phytochemical screening}

Table 1: Level of phytoconstituents' presence in samples

\begin{tabular}{|c|c|c|c|c|}
\hline \multirow[t]{2}{*}{ Tests } & \multicolumn{4}{|c|}{ Samples } \\
\hline & NALE & NALM & NABE & NABM \\
\hline $\begin{array}{l}\text { Test for Alkaloids: } \\
\text { Mayer's Test } \\
\text { Wagner's Test } \\
\text { Dragendorff's reagent }\end{array}$ & $\begin{array}{c}- \\
++ \\
-\end{array}$ & $\begin{array}{c}+ \\
++ \\
-\end{array}$ & $\begin{array}{c}- \\
++ \\
-\end{array}$ & $\begin{array}{c}- \\
++ \\
-\end{array}$ \\
\hline $\begin{array}{l}\text { Tests for glycosides: } \\
\text { Cardiac glycosides (Keller-Killiani test) } \\
\text { Anthraquinone glycosides (Borntrager's test) }\end{array}$ & $\begin{array}{c}++ \\
-\end{array}$ & $\begin{array}{c}++ \\
-\end{array}$ & $\begin{array}{c}++ \\
+\end{array}$ & $\begin{array}{c}++ \\
-\end{array}$ \\
\hline $\begin{array}{l}\text { Tests for steroids: } \\
\text { Liebermann-Burchard test } \\
\text { Salkowski test }\end{array}$ & $\begin{array}{l}- \\
-\end{array}$ & $\begin{array}{l}- \\
-\end{array}$ & - & $\begin{array}{l}- \\
-\end{array}$ \\
\hline $\begin{array}{l}\text { Tests for Saponins: } \\
\text { Foam test }\end{array}$ & - & - & - & - \\
\hline
\end{tabular}

+ slightly present, ++ highly present, -absent

\section{TLC Screening}

\section{RESULTS AND DISCUSSION:}

In the study, ethyl acetate (medium polar) and methanol (polar) were used to extract both polar and slightly polar compounds of $N$. arbortristis leaf and bark. A total of four samples were designated as NALE, NALM, NABE, and NABM. The samples showed distinguishable features in phytochemical screening and antioxidant activity, which indicates the impact of the solvent's polarity and the unequal distribution of phytoconstituents in leaf and bark.
A. $254 \mathrm{~nm}$

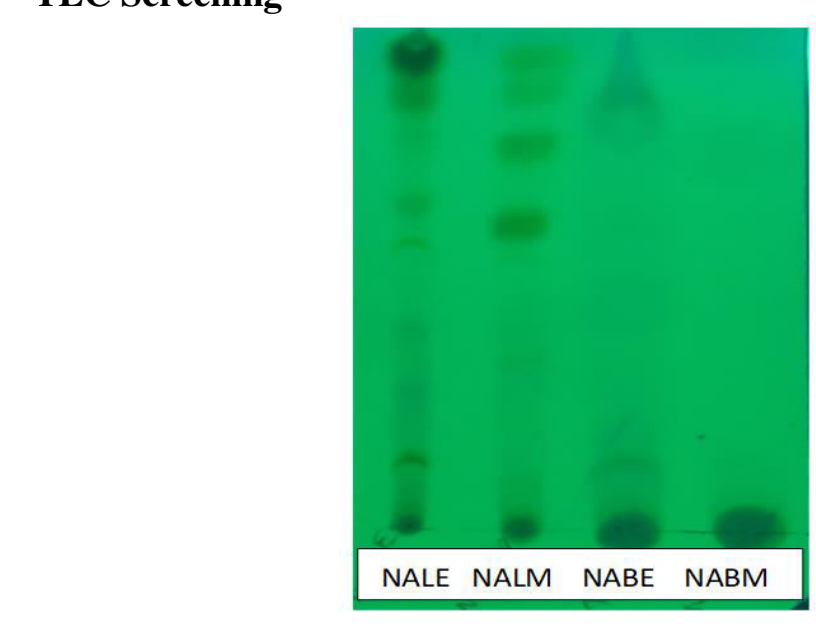

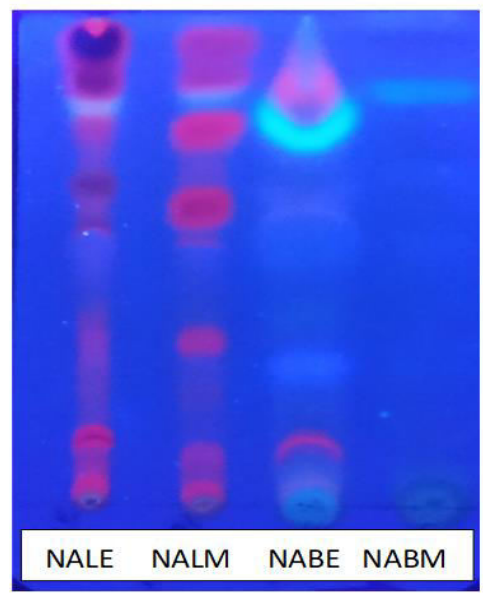

B. $365 \mathrm{~nm}$

Fig 1: Screening of NALE, NALM, NABE, NABM by thin-layer chromatography (TLC) at (A) 254 nm and (B) $365 \mathrm{~nm}$ UV light. 
Table 2: List of color development in TLC plate and probable compounds of the samples

\begin{tabular}{|c|c|c|c|c|}
\hline $\begin{array}{c}\text { Test } \\
\text { Sample }\end{array}$ & Visual color & UV light at $254 \mathrm{~nm}$ & UV light at 365nm & Remarks on probable compounds \\
\hline NALE & Green, Dark & $\begin{array}{c}\text { Dark, } \\
\text { Dark green, Bluish }\end{array}$ & $\begin{array}{l}\text { Red, Black, Light, } \\
\text { Brownish, } \\
\text { Light red }\end{array}$ & $\begin{array}{l}\text { Chlorophyll, } \\
\text { Phenolics, Quinolone, Glycosides, } \\
\text { Anthocyanin }\end{array}$ \\
\hline NALM & Green & $\begin{array}{l}\text { Two dark, } \\
\text { Light, Bluish }\end{array}$ & Red, Sky blue, light & $\begin{array}{l}\text { Chlorophyll, } \\
\text { Phenolics, Anthraquinone, Glycosides }\end{array}$ \\
\hline NABE & Brown, Yellow & Two dark, Light, & Red, Bluish, Blue & $\begin{array}{l}\text { Quinolone, Anthraquinone, } \\
\text { Flavonoids, Phenolics, Terpenoids, } \\
\text { Glycosides }\end{array}$ \\
\hline NABM & Brown & $\begin{array}{l}\text { Two dark } \\
\text { Light }\end{array}$ & Blue, Reddish & Phenolics, Glycosides, Quinolone \\
\hline
\end{tabular}

In Wagner's test and Keller-Killiani test, all samples explored the presence of high-level alkaloids and cardiac glycoside. NABE had a slight presence of anthraquinone glycosides. Test for steroids and saponin presented negative results in every case.

TLC screening showed several spots in both long and short of UV light for the samples except NABE in the solvent system (Toluene: Ethyl acetate $=90 \%: 10 \%$ ). The developed plates represented the presence of different types of probable compounds mentioned in Table 2. All samples had a chance to have alkaloids, phenolic compounds, and glycosides.
The qualitative phytochemical screening tabulated in Table 1 show the presence of alkaloids and cardiac glycosides to a large extent. Alkaloids represent a range of heterocyclic compounds with broad biological activity such as anti-inflammatory, antipyretic, neuroactive, antitumor, anticancer, and immunemodulatory effects (Roberts, 2013). Cardiac glycosides are a unique type of compound and are effectively used in cardiac failure. It also has antitumor and antiviral activity (Morsy, 2017). Furthermore, the multi-colored TLC screening spots revealed the plant as a repository of a good amount of phytoconstituents.

\section{Antioxidant test}

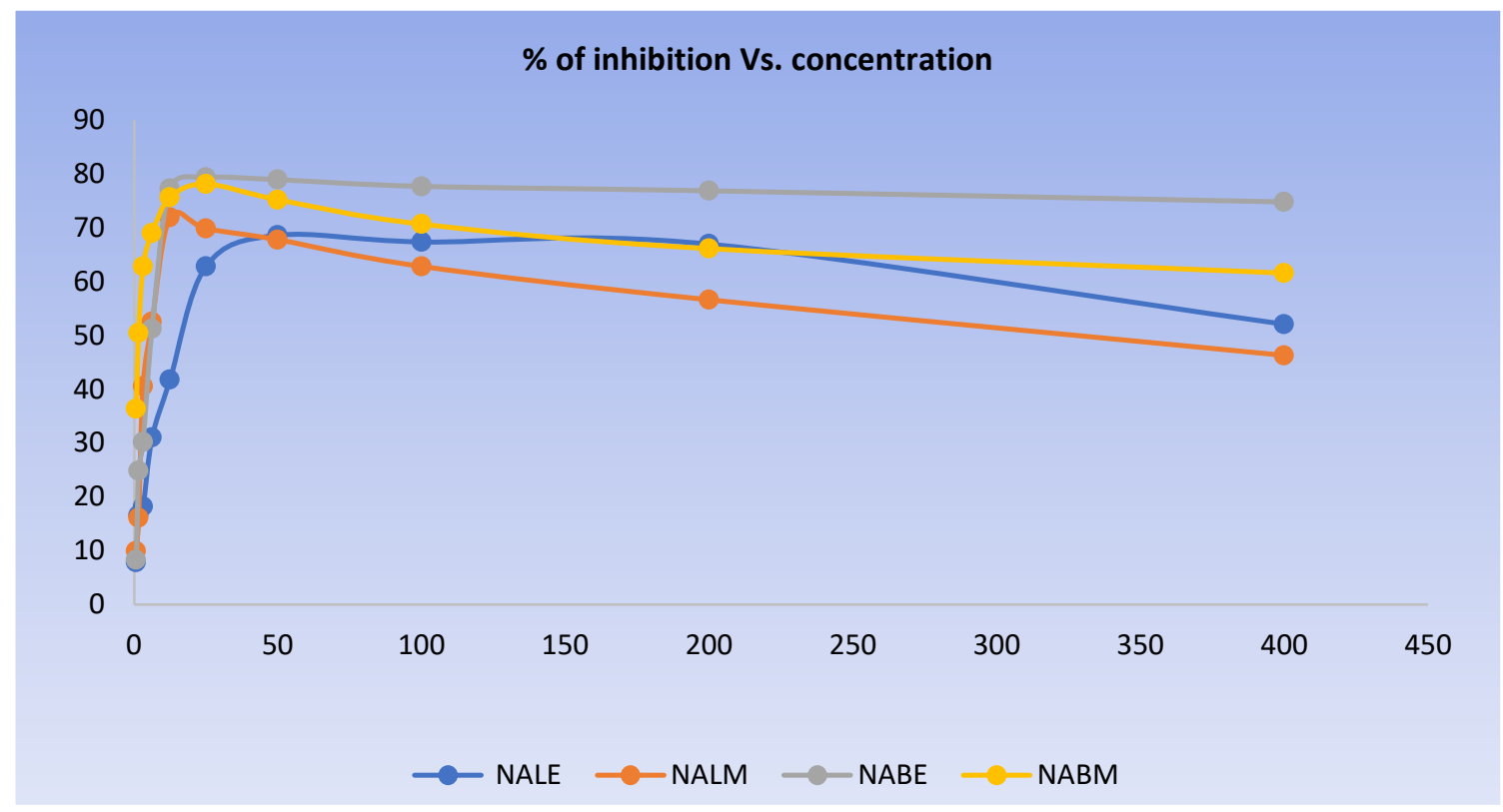

Fig 2: DPPH radical scavenging activity curve of leaf and bark extract of the plant $N$. arbortristis. 
The percentage of DPPH radical scavenging tendency followed a similar pattern with concentrations (Fig 2). The first five doses of every sample had a sharp rise of free radical inhibition, but after that, it had a slight fall of inhibitory activity with the increase of dose (Shahen et al., 2019). The results showed a dose-response relationship from $0.752 \mu \mathrm{g} / \mathrm{ml}$ to $12.5 \mu \mathrm{g} / \mathrm{ml}$, as mentioned by Khanapur et al. (2014).

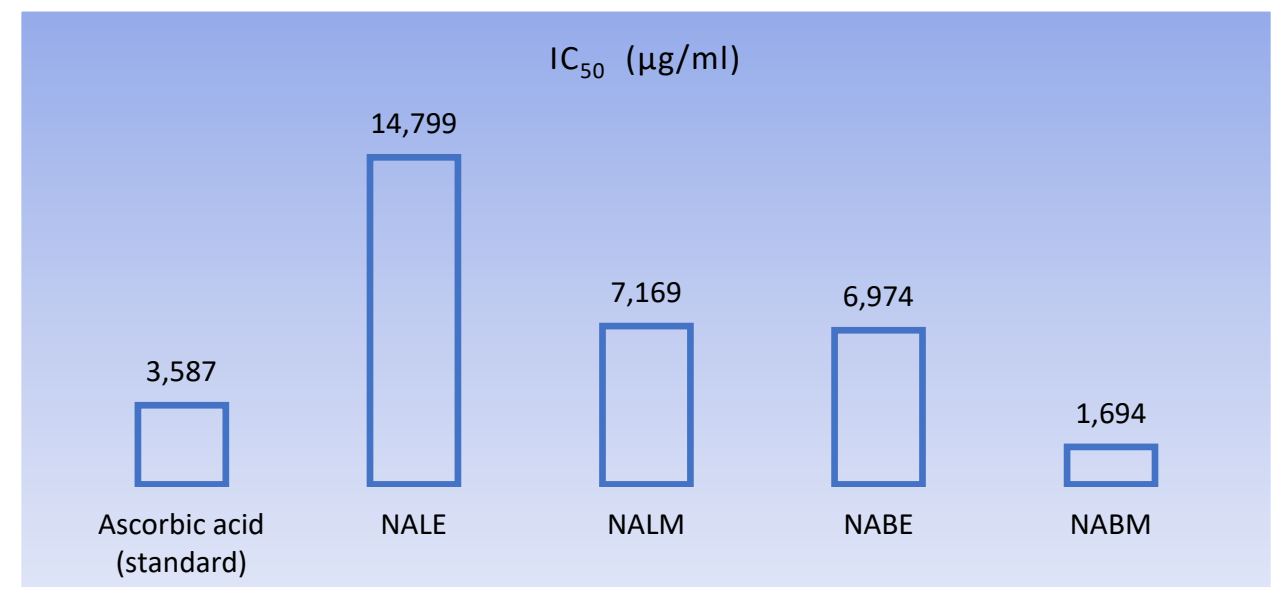

Fig 3: $\mathrm{IC}_{50}$ values of standard and samples.

DPPH assay is very sensitive to qualify and quantify the free radical scavenging property, and the present study carried out to determine the plant's antioxidant potential by this method. $\mathrm{IC}_{50}$ values of NALE, NALM, NABE and NABM are $14.799 \mu \mathrm{g} / \mathrm{ml}, 7.169$ $\mu \mathrm{g} / \mathrm{ml}$. $6.974 \mu \mathrm{g} / \mathrm{ml}$, and $1.694 \mu \mathrm{g} / \mathrm{ml}$, respectively, where for ascorbic acid; the value is $3.587 \mu \mathrm{g} / \mathrm{ml}$ (Fig 3). The extracts of bark showed comparatively better activity than the leaf. Whereas, methanolic extracts are highly capable of scavenging the radicals than the ethyl acetate extracts. $\mathrm{IC}_{50}$ of NALM is half of NALE, and for NABM, the value is one-fourth of NABE. So, the polar solvent might had dissolved a few more-polar phytochemicals that had good antioxidant activity. So, the plant might contain polyphenols, carotenoids (Sasikumar et al., 2010). Interestingly, the IC50 values of extracts are not very far from this study's standard (ascorbic acid). NABM shoed more potential than the standard that directly highlights the plant's usefulness as an antioxidant (Rathee et al., 2007).

\section{Antimicrobial test}

The mean zone of inhibition of ciprofloxacin (20 $\mu \mathrm{g} / \mathrm{disc}$ ) against the five test bacteria was $19 \mathrm{~mm}$ and the inhibitory zone for ketoconazole $(20 \mu \mathrm{g} / \mathrm{disc})$ was $16 \mathrm{~mm}$ against yeast. But unexpectedly, the study failed to find any antibacterial or antifungal effect of the samples at the dose $40 \mu \mathrm{g} / \mathrm{disc}$, though, several UniversePG I www.universepg.com studies revealed this activity to a small extent (Ankita et al., 2014; Mosaib et al., 2020; Kumar et al., 2019). Therefore, the research suggests conducting studies on a larger dose than the study.

\section{CONCLUSION:}

The present study on ethyl acetate and methanolic extracts of $N$. arbortristis explored a profile of several phytoconstituents and an excellent antioxidant activity. Phytochemical screening marked the high presence of alkaloids and glycosides. Though no antimicrobial activity is observed, the amazing radical scavenging capability of the plant pointed out its potential to use against aging, cancer, cardiac disease. Therefore, the plant is a good source of bioactive compounds and might be a potential drug discovery source.

\section{ACKNOWLEDGEMENT:}

I am grateful to Almighty God to give me the ability to complete this study. I give thanks to my respected Head of the Department for his inspiration and support to the successful research study.

\section{CONFLICTS OF INTEREST:}

The author (s) declared no potential conflicts of the interest with respect to the research, authorship and/or publication of this article. 


\section{REFERENCES:}

1) Agrawal J., Pal A. (2013). Nyctanthes arbortristis Linn. A critical ethnopharmacological review. J. Ethnopharmacol. 146(3): 645-658. https://doi.org/10.1016/j.jep.2013.01.024

2) Ankita C., Mamta G., Shikha B. (2014). Antimicrobial potential of Nyctanthes arbortristis and isolation of Colletotrichum gleosporioides an endophyte. J. Pharm. Res. 8(8): 1082-1090.

https://jprsolutions.info/files/final-file-58031 f6ccdd497.55908389.pdf

3) Bladt S. (2004). Plant drug analysis - A thin layer chromatography atlas 2nd edition. New Delhi: Thompson Press Ltd.

https://www.springer.com/gp/book/97836420057 $\underline{32}$

4) Harborne J. B. (2005). Phytochemical methods - A guide to modern techniques of plant analysis. New Delhi: Springer Pvt. Ltd. https://www.springer.com/gp/book/97804125726 $\underline{09}$

5) Huang Y. L., Oppong M.B., Guo Y., Wang L. Z., Fang S. M., Deng Y. R., Gao X. M., (2019). The Oleaceae family: A source of secoiridoids with multiple biological activities. Fitoterapia. 136: 104155.

6) Jensen S. R., Nielsen B. J. (1982). Iridoid glucosides in Fouquieriaceae. Phytochemistry. 21: 1623-9. https://doi.org/10.1016/S0031-9422(82)85028-0

7) Joshi N., Bhatt S., Dhyani S., Nain J. (2013). Phytochemical screening of secondary metabolites of Argemone mexicana Linn. Flowers. Int. J. Curr. Pharm. Res. 5(2): 144147.

8) Kaur G. J., Arora D. S. (2009). Antibacterial and phytochemical screening of Anethum graveolens, Foeniculum vulgare, and Trachyspermum ammi. BMC Complement Altern. Med. 9(1): 30. https://doi.org/10.1186/1472-6882-9-30

9) Khanapur M., Avadhanula R. K., Setty O. H. (2014). In vitro antioxidant, antiproliferative, and phytochemical study in different extracts of Nyctanthes arbortristis flowers. BioMed.
Res. Int. 2014: 291271.

https://doi.org/10.1155/2014/291271

10) Kumar D., Singh A., Gupta E., Patel S. L., Gupta V. (2019). Phytochemical Analysis and Screening of Antimicrobial Activity of Psidium guajava and Nyctanthes arbortristis extract against Oral Pathogens. J. Chem. Pharm. Res. 11(5): 70-78.

11) Makkar H. P., Siddhuraju P., Becker K. (2007). Plant secondary metabolites. Totowa, NJ, USA. Humana Press. 101-106. https://www.springer.com/gp/book/97815882999 $\underline{32}$

12) Mathuram V., Kundu A. B. (1991). A reinvestigation of the structures of arbortristosides A and B from Nyctanthes arbortristis. J. Nat. Prod. 54: 257-60.

13) Mathuram V., Patra A., Kundu A. B. (1997). A phenyl propanoid glycoside from $N$. arbortristis. J. Indian Chem. Soc. 74: 653-5.

14) Morsy N. (2017). Cardiac glycosides in medicinal plants. Aromatic and Medicinal PlantsBack to Nature. London: Intechopen. 29-45.

15) Mosaib MG, Islam R, Mahmud S, Imran MAS, and Islam S. (2020). Antibacterial activity of Cissus quadrangularis stem extract on the pathogenic and industrial waste watered bacteria. Eur. J. Med. Health Sci., 2(2), 28-38. https://doi.org/10.34104/ejmhs.020.28038

16) Raaman N. (2006). Phytochemical techniques. New India Publishing, 318 pages. https://www.nipabooks.com/info/978818942230 1/phytochemical-techniques

17) Rani C., Chawla S., Mangal M., Mangal A. K., KajlaS., Dhawan A. K. (2012). Nyctanthes arbortristis Linn. (Night Jasmine): A sacred ornamental plant with immense medicinal potentials, Ind. J. of Trad. Know. 11(3), 427435.

http://nopr.niscair.res.in/bitstream/123456789/14 383/1/IJTK\%2011(3)\%20427-435.pdf

18) Rathee J. S., Hassarajani S. A., Chattopadhyay S. (2007). Antioxidant activity of Nyctanthes arbortristis leaf extract. Food Chem. 103(4): 1350-1357.

https://europepmc.org/article/agr/ind43907506

19) Rathore A., Srivastava V., Srivastava K. C., 
Tandon J. S. (1990). Iridoid glucosides from Nyctanthes arbortristis. Phytochemistry. 29: 1917-20.

20) Roberts M. F. (2013). Alkaloids: biochemistry, ecology, and medicinal applications. Springer Science \& Business Media. https://www.springer.com/gp/book/97803064546 $\underline{53}$

21) Rony MH, Imran MAS, Islam R, Mosaib MG, and Sheikh MR. (2019). Determination of antimicrobial activity of medicinal plant Cassia obtusifolia L. (Chakunda) leaf extract on selected pathogenic microbes, Am. J. Pure Appl. Sci., 1(6), 59-69. https://doi.org/10.34104/ajpab.019.01959069

22) Santoyo S., Cavero S., Jaime L., Ibanez E., Senorans F. J., Reglero G. (2005). Chemical composition and antimicrobial activity of Rosmarinus officinalis L. essential oil obtained via supercritical fluid extraction. J. food prot. 68(4): 790-795.

https://doi.org/10.4315/0362-028x-68.4.790

23) Sasikumar J. M., Mathew G. M., Teepica P. D. D. (2010). Comparative studies on antioxidant activity of methanol extract and flavonoid fraction of Nyctanthes arbortristis leaves.
EJEAFChe. 9(1): 227-33.

24) Shahen MZ, Mahmud S, Uddin ME and Alam MS. (2019). Effect of antibiotic susceptibility and inhibitory activity for the control of growth and survival of microorganisms of extracts of Calendula officinalis, Eur. J. Med. Health Sci. 1(1), 1-9. https://doi.org/10.34104/ejmhs.0190109

25) Shukla A. K., Patra S., Dubey V. K. (2011). Deciphering molecular mechanism underlying antileishmanial activity of Nyctanthes arbortristis, an Indian medicinal plant. $J$. Ethnopharmacol., 134(3): 996-998. https://doi.org/10.1016/j.jep.2011.01.044

26) Singh K. L., Roy R., Srivastava V., Tandon J. S. (1995). Arborside D, a minor iridoid glucoside from Nyctanthes arbortristis. J. Nat. Prod. 58: 1562-4.

27) Tuntiwachwuttikul P., Rayanil K. Taylor W. C. (2003). Chemical constituents from the flowers of Nyctanthes arbortristis. Science Asia. 29(1): 21-30. https://doi.org/10.2306/scienceasia1513-1874. $\underline{2003.29 .021}$

Citation: Talukder S, Uddin MS, Ferdous M, and Baral PK. (2020). Phytochemical screening and bioactivity determination of ethyl acetate and methanolic extracts of leaf and bark of the plant Nyctanthes arbortristis L., Eur. J. Med. Health Sci., 2(6), 145-151. https://doi.org/10.34104/ejmhs.020.01450151 क्) 